\title{
Članci prihvaćeni za publiciranje / Accepted Manuscripts
}

\author{
ZDRAVSTVENA EDUKACIJA/HEALTH CARE EDUCATION \\ SIGURNOST BOLESNIKA/PATIENT SAFETY \\ Uporaba metoda palijativne skrbi u djece \\ Implementation of palliative care methods in children \\ Marija Šilje

\section{RESEARCH / ISTRAŽIVANJE ORIGINALNI ČLANAK / ORIGINAL ARTICLE} \\ Učestalost depresije u starijoj životnoj dobi na području grada Dubrovnika \\ The incidence of depression in the elderly in the city of Dubrovnik \\ Anita Budimir
}

\section{RESEARCH / ISTRAŽIVANJE ORIGINALNI ČLANAK / ORIGINAL ARTICLE}

Funkcionalna sposobnost, samoprocjena zdravlja i zadovoljstvo životom starijih osoba u domu umirovljenika Functional ability, self-rated health and life satisfaction of elderly people in a retirement home Manuela Roso

\author{
Pedijatrijski pacijent i cistična fibroza \\ Pediatric patient with cystic fibrosis \\ Marija Šilje
}

NURSING EDUCATION / ZDRAVSTVENA EDUKACIJA SIGURNOST BOLESNIKA/PATIENT SAFETY

\author{
NURSING EDUCATION / EDUKACIJA U SESTRINSTVU \\ PREGLEDNI ČLANAK/REVIEW ARTICLE \\ Uloga medicinske sestre u prepoznavanju znakova zlostavljanja osoba starije dobi \\ The role of nurses in recognizing the abuse of elderly people \\ Sonja Šare, Marija Ljubičić \\ HEALTH CARE EDUCATIOM / ZDRAVSTVENA EDUKACIJA \\ PREGLEDNI ČLANAK/REVIEW ARTICLE \\ Maligna bolest prostate \\ Malignant disease of prostatic node \\ Snježana Busančić, Zdravko Cvitanović, Irena Matulović, Marija Milić, Mario Šljuka, Marija Šilje
}

\section{NURSING EDUCATION / ZDRAVSTVENA EDUKACIJA PREGLEDNI ČLANAK/REVIEW ARTICLE \\ Komunikacijske vještine medicinske sestre/tehničara s psihijatrijskim bolesnicima Communication skills of nurses / technicians with psychiatric patients Marija Šilje}

\author{
RESEARCH / ISTRAŽIVANJE \\ KRATKO PRIOPČENJE/BRIEF COMMUNICATION \\ Utjecaj edukacijskih tečaja na informiranost trudnica o dojenju \\ The impact of educational courses on level of awareness to pregnant women about breastfeeding \\ Tina Škugor, Šimunović Maria, Lubina Ana, Sekondo Deniza, Žunić Hrvojka
}




\section{ISTRAŽIVANJE / RESEARCH KRATKO PRIOPČENJE / BRIEF COMMUNICATION \\ Prisutnost nasilja u dubrovačko-neretvanskoj županiji \\ The presence of violence in the Dubrovnik-Neretva County \\ Sara Tomic}

\section{PROFESIONALNA SESTRINSKA PRAKSA/NURSING PRACTICE KRATKO PRIOPČENJE / BRIEF COMMUNICATION}

Mišljenje medicinskih sestara i tehničara o metodama vođenja sestrinske dokumentacije-Iskustva županijske bolnice

Opinion of nurses and technicians about the methods of management nursing documentation-Experiences from County Hospital Barbara Aleksić, Hana Brković, Ivana Jupek, Barbara Lešević, Edin Bošnjaković

\section{RESEARCH / ISTRAŽIVANJE ORIGINALNI ČLANAK/ORIGINAL ARTICLE}

Stavovi studenata Diplomskog studija sestrinstva Medicinskog fakulteta Sveučilišta u Zagrebu o informatizaciji Attitudes of graduate nursing students, Faculty of Medicine, University of Zagreb on computerization Strapajević Damir, Aranđel Mihajlović

\section{KRATKO PRIOPČENJE / BRIEF COMMUNICATION}

Učestalost muške populacije u sestrinstvu kroz povijest i danas

The frequency of the male population in nursing throughout history and today

Dijana Čizik, Matea Čikeš, Matea Gavranić, Tanja Marjanović, Petra Mlikota

\section{PROFESIONALNA SESTRINSKA PRAKSA / NURSING PRACTICE ORIGINALNI ČLANAK /ORIGINAL ARTICLE}

Prevalencija dekubitalnih ulkusa u Općoj bolnici Dubrovnik, Croatia

The prevalence of pressure ulcers in the General Hospital Dubrovnik, Croatia

Andrea Butigan, Dominik Landeka, Ivana Marić, Martina Martinović, Sandra Švarc

\section{MIDWIFERY / PRIMALJSTVO}

\section{ORIGINALNI ČLANAK/ORIGINAL ARTICLE}

Procjena kvalitete edukacije medicinskih sestara u pripremi trudnice za porod

Assessment of the Quality Education of Nurses in Preparing Pregnant Women for Childbirth

Jadranka Ristić, Vesna Turuk, Ružica Mrkonjić

\section{JAVNO ZDRAVSTVO/PUBLIC HEALTH

KRATKO PRIOPČENJE / BRIEF COMMUNICATION

Javno zdravstveni značaj spolno prenosivih infekcija u Dubrovačko-neretvanskoj županiji

The public health significance of sexually transmitted infections in the Dubrovnik-Neretva County

Ivana Jarmanović

\section{JAVNO ZDRAVSTVO / PUBLIC HEALTH KRATKO PRIOPČENJE / BRIEF COMMUNICATION}

Stupanj razumijevanja značenja pojma dijabetes u populaciji mjesta Postranje The degree of understanding of the meaning of diabetes in the population of Postranje

Maris Miloslavić, Leona Matuško

\section{PUBLIC HEALTH /JAVNO ZDRAVSTVO PREGLEDNI ČLANAK / REVIEW ARTICLE}

Psihosocijalna prilagodba bolesnika poslije amputacije donjeg ekstremiteta

Psychosocial adaptation of patients after amputation of the lower extremities Ivana Gudelj-Velaga 


\section{RESEARCH / ISTRAŽIVANJE}

ORIGINALNI ČLANAK/ORIGINAL ARTICLE

Razlike u stavovima i znanju oko cijepljenja roditelja predškolske djece i zdravstvenih djelatnika

Differences in attitudes and knowledge about vaccination of preschool children parents and health care professionals

Zrinka Puharić, Renata Pintar, Mirna Žulec, Rudolf Kiralj, Živko Stojčić

\section{HEALTH CARE EDUCATION / ZDRAVSTVENA EDUKACIJA ORIGINALNI ČLANAK/ORIGINAL ARTICLE}

Zadovoljstvo korisnika zdravstvenim uslugama u specijalnoj bolnici za medicinsku rehabilitaciju Daruvarske toplice Level of satisfaction of customers in health services at the special hospital for medical rehabilitation Daruvarske Toplice Zdenka Bis, Sabina Bis

\section{HEALTH CARE EDUCATIOM / ZDRAVSTVENA EDUKACIJA PREGLEDNI ČLANAK/REVIEW ARTICLE \\ Maligna bolest prostate \\ Malignant disease of prostatic node \\ Snježana Busančić, Zdravko Cvitanović, Irena Matulović, Marija Milić, Mario Šljuka, Marija Šilje}

\section{RESEARCH / ISTRAŽIVANJE}

\section{ORIGINALNI ČLANAK / ORIGINAL ARTICLE}

Zadovoljstva studenata stupnjem kvalitete diplomskog studija sestrinstvo Medicinskog fakulteta Osijek Students level of satisfaction with graduate nursing studies at Medical Faculty Osijek

Batrnek Tihana, Gašpert Mateo, Grcić Toni, Krstić Tea, Kovačić Anja, Vuksanović Milica

\section{PROFESIONALNA SESTRINSKA PRAKSA / NURSING PRACTICE} ORIGINALNI ČLANAK / ORIGINAL ARTICLE

Uloga medicinske sestre u prevenciji infekcija izazvanih multirezistentnim bakterijama

Role of nurse in prevention of infections caused by multi-drug resistant bacteria

Darija Knežević, Duška Jović, Snežana Petrović-Tepić

\section{NURSING EDUCATION / ZDRAVSTVENA EDUKACIJA PREGLEDNI ČLANAK/REVIEW ARTICLE}

Sindrom post-intenzivne skrbi

Post-intensive care syndrom

Irena Kovačević, Sonja Kalauz, Valentina Krikšić, Adriano Friganović, Boris Ilić, Štefanija Ozimec-Vulinec

\section{POVIJEST SESTRINSTVA I MEDICINE/HISTORY OF NURSING AND MEDICINE PREGLEDNI ČLANAK/REVIEW ARTICLE}

Povijest i evolucija sestrinstva u operacijskoj dvorani

The history and evolution of nursing in the operating room

Blaženka Kozina, Diana Dragija

\section{RESEARCH / ISTRAŽIVANJE}

\section{ORIGINALNI ČLANAK / ORIGINAL ARTICLE}

Utjecaj cijene koštanja prehrabenih proizvoda na stupanj kvalitete starijih osoba u domaćoj okolini

The impact of costs of nutrition's on the overall quality of nutrition of the elderly population in the local environment Nataša Mlinar Reljić, Marijana Lesničar, Cirila Hlastan Ribič, Jadranka Stričević1, Sabina Fijan

\section{RESEARCH / ISTRAŽIVANJE}

\section{ORIGINALNI ČLANAK / ORIGINAL ARTICLE}

Pojavnost alimentarnog mukozitisa kod pacijenata na klinici za onkologiju Kliničkog Bolničkog Centra Rebro-Zagreb The incidence of alimentary mucositis in patients at Clinic for Oncology in the Clinical Hospital Centre Rebro-Zagreb Danijela Jonjić, Marica Novak, Jasminka Miličević, Vesna Kralj-škoc 


\section{EDUKACIJA U SESTRINSTVU / NURSING EDUCATION PREGLEDNI ČLANAK / REVIEW ARTICLE \\ Uloga anesteziološke sestre/tehničara u postupku eksplantacije organa \\ The role of anaesthetic nurse/technician in organ donor programme \\ Jadranko Topić, Višnja Nesek Adam, Dario Zirdum}

\section{HEALTH CARE EDUCATION / ZDRAVSTVENA EDUKACIJA ESEJ/ESSAY}

Kronična bol; opća saznjanja, metode liječenja i specifična problematika

Chronic pain; general remarks, methods of treatment and specific issues

Marija Petrović, Branka Rimac

\section{PROFESIONALNA SESTRINSKA PRAKSA / NURSING PRACTICE PREGLEDNI ČLANAK /REVIEW ARTICLE \\ Zdravstvena njega osoba s autonomnom disrefleksijom \\ Health care of people who are suffering from autonomic Dysreflexia \\ Nada Strčić, Dean Markić}

\section{NURSING EDUCATION/EDUKACIJA U SESTRINSTVU PREGLEDNI ČLANAK/REVIEW ARTICLE \\ Sestrinske dijagnoze u zdravstvenoj njezi umirućih bolesnika/ \\ Nursing diagnoses in healthcare of daying patient \\ Sonja Šare, Ana Marija Prka, Suzana Konjevoda \\ RESEARCH / ISTRAŽIVANJE ORIGINALNI ČLANAK / ORIGINAL ARTICLE}

Spolno ponašanje adolescenata; Usporedba adolescenata drugih i četvrtih razreda strukovne škole i gimnazije

Sexual behavior of adolescents; Comparison of adolescents of second and fourth grade of vocational school and gymnasium Martin Trubelja, Mario Sambolec

\section{RESEARCH / ISTRAŽIVANJE ORIGINALNI ČLANAK / ORIGINAL ARTICLE}

Stavovi prema duševnim bolesnicima u društvu - usporedba u odnosu na odabrane socio-demografske čimbenike Attitudes towards patients with mental disorders in society - comparison in relation to selected socio-demographic factors Tina Škugor,Joško Sindik

\section{RESEARCH / ISTRAŽIVANJE ORIGINALNI ČLANAK / ORIGINAL ARTICLE}

Sociološki osvrt na devijantno ponašanje maloljetnika u Blatu na otoku Korčuli

Sociological review of the deviant behavior of juveniles in Blato on the island of Korcula

Katarina Paušek, Ivica Žuvela Piculin, Drago Paušek, Joško Sindik 